\title{
WACANA WAYANG GOLEK CEPOT KEMBAR DARI GIRIHARJA 3 (Kajian Struktural dan Etnopedagogik)
}

\author{
Gun Gun Cahya Gumilar \\ Pos-el: Gun.GunzSunda@yahoo.com
}

\begin{abstract}
Abstrak
Penelitian ini bertujuan untuk mengetahui struktur wacana wayang golek dan nilai-nilai etnopedagogik yang ada dalam lakon Cepot kembar dari Giriharja 3. Metode yang dipakai dalam penelitian ini adalah metode deskriptif. Maksud yang ingin dicapai dalam penelitian ini adalah menggambarkan dan memilah-milah struktur wacana wayang golek dan nilai-nilai etnopedagogik. Tehnik yang digunakan untuk mengumpulkan data dalam penelitian ini adalah menggunakan telaah pustaka, tehnik observasi, dan tehnik transliterasi. Untuk mengolah data yang terkumpul menggunakan tehnik analisis langsung. Data yang dianalisis yaitu wacana wayang golek hasil transkripsi. Untuk mengolah nilai-nilai etnopedagogik, digunakan metode heurmeunitik. Berdasarkan hasil penelitian, diperoleh kesimpulan bahwa struktur wacana wayang golek Cepot kembar ada 61 struktur carita wayang. Dari struktur tersebut, dibagi menjadi 4 bagian. Yaitu murwa (satukali), kakawén (11 kali), nyandra (19 kali), dan antawacana (29 kali). selain itu juga, dari hasil penelitian ini diperoleh data nilai-nilai etnopedagogik dalam 20 percakan. Dari percakapan tersebut dibagi menjadi 3 bagian. Yaitu moral manusia kepada yang menciptakannya ( 7 kali, moral manusia kepada dirinya sendiri (3 kali), moral manusia dengan manusia ( 8 kali), dan moral manusa dalam menemukan kepuasan lahir dan batin (2 kali)
\end{abstract}

Kata kunci: wacana wayang golek, struktural, etnopedgogik

\section{THE DISCOURSE OF THE PUPPET SHOW CEPOT KEMBAR OF GIRIHARJA 3 (The Study of Structure and Ethnopedagogy)}

\begin{abstract}
This study determines the structure of the discourse of Wayang Golek (puppet show); and the ethnopedagogical values that exist in the play Cepot Kembar of Giriharja 3. The method used in this research was descriptive method. The goals are to describe and to sort out the structure of the discourse of the puppet show and its ethnopedagogical values. The technique used to collect data in this study was the use of literature review, observation, and transliteration. The collected data was processed by using the direct analysis. The transcript data were analyzed. Then, to find out the ethnopedagogical values, hermeneutics method was used. , Based on the research results, it is concluded that the discourse structure of the puppet show Cepot Kembar has 61 narrative structures. The structures are divided into 4 sections. They are murwa (one time), kakawén (11 times), nyandra (19 times), and Antawacana (29 times). In addition, this study gained the ethnopedagogical values in 20 conversations, which are divided into 3 parts. They are human moral toward The Creator (7 times), toward themselves (3 times), toward fellow-human (8 times), and in finding physical and psychological satisfactions (2 times).
\end{abstract}

Keywords: The Discourse of Wayang Golek, Structural, Ethnopedgogy 


\section{PENDAHULUAN}

Bahasa merupakan alat komunikasi manusia atau alat interaksi yang hanya dimiliki oleh manusia. Dalam kehidupan masyarakat, manusia juga bisa menggunakan alat komunikasi yang lainnya selain dari bahasa. Tapi bahasa merupakan alat komunikasi yang paling bagus, paling sempurna, dibandingkan dengan alat komunikasi lain yang digunakan hewan. Bahasa merupakan ciri khas suatu bangsa. Artinya tiap daerah mempunyai cirikhas bahasa sendiri-sendiri.

Bagian bahasa yang paling lengkap dalam hirarki gramatikal adalah wacana. Wacana ada banyak jenisnya. Diantarnya adalah wacana wayang golek. Wayang golek merupakan gambaran kehidupan manusia di muka bumi. Selain itu dalam kesenian wayang golek penuh dengan nilainilai yang bisa dicontoh oleh manusia dalam menjalankan kehidupan di masyarakat.

Pagelaran wayang golek pada dasarnya menggunakan bahasa sunda. tapi seiring dengan perkembangan jaman dan keilmuan serta teknologi para remaja saat ini kurang menyukai pada kesenian tradisional hususnya kesenian wayang golek yang seutuhnya menggunakan bahasa daerah (sunda). oleh karena itu pagelaran wayng golek dalam dialog percakapannya sering kali dicampur dengan bahasa lain, contonya, bahasa Indonesia, bahasa Inggris, atau menggunakan bahasa-bahasa yang sedang populer di kalangan remasa saat ini. Wayang merupakan salah satu unsur kebudayaan yang ada di Indonesia yang mempunyai nilai-nilai seni, pendidikan, falsapah yang tinggi. Mulyono (1982, hal. IX). Wayang golek merupakan seni pertunjukan wayang yang terbuat dari boneka kayu, biasanya populer di daerah tanah pasundan. (Pasha, 2011, hal 26).

Perkembangan jaman tetunya yang menjadi sebab dari para remaja saat ini sudah tidak mengenal seni tradisional. Melemahnya sikap positif, sikap silih asah, silih asih, dan silih asuh yang menyebabkan para remaja kehilangan jati diri kesundaannya. Remaja saat ini lebih suka terhadap kesenian bangsa luar daripada kesenian bangsa sendiri.

Oleh sebab itu, perlu adanya usaha yang dilaksanakan secara konsisten. Termasuk mengungkab struktur wacana wayang golek dalam cerita Cepot Kembar dari Giriharja . penelitian ini mempunyai tujuan untuk mengenalkan struktur wacana wayang golek, struktur cerita wayng golek, dan nilai-nilai etnopedagogik yang terkandung dalam cerita wayang Cepot kembar.

\section{METODE}

Penelitian ini termasuk kedalam penelitian kualitatif dengan metode deskriptif dengan maksud yang ingin dicapai adalah mengambarkan serta memilah-milah struktur wacana wayang golek, struktur cerita wayang golek dan nilai-nilai etnopedagogik yang ada dalam cerita wayang Cepot Kembar dari Giriharja 3.

Metode deskriptif juga bertujuan untuk menyelesaikan persoalan0persoalan yang aktual dengan cara mengumpulokaan data, nyusun bagian-bagian, menganalisis, dan menapsirkan data. Sedangkan tehnik penelitian yang dipake meliputi telaah pustaka dan analisis video.

\section{HASIL DAN PEMBAHASAN}

\section{a. Rikasan Cerita}

Dipadepokan parewaran, Abiasa kedatangan Arjuna dan Gatotkaca dengan maksud untuk menanyakan kepada abiasa, apakah benar hilangnya layang jamus kalimusada benar dicuri oleh si Cepot. Abiasa tidak menjawab. Arjuna dan Gatotkaca malah disuruh menanyakan kepada yang lebih berhak dan lebih tau atau ahlinya yaitu Prabu Batara Kresna. Berangkatlah Arjuna menemui Batara Kresna sednagkan Gatotkaca menemui ayahandanya Bima yang sedang mencari si Cepot.

Adapun alasan si Cepot jelmaan ini mencuri layang jamus kalimusada ingin 
menatar para pejabat atau para Negarawan dan ingin menyampaikan butir dari layang jamus kalimusada kepada masarakat yang selama ini dinilainya bertolak belakang dan tidak harmonis.

Arjuna, gatotkaca, Kresna, dan Bima menycoba membawa kembali layang jamus kalimusada dari tangan Cepot jelemaan. Tapi usahanya itu gagal semua. Semua pulng kembali ke Amarta, kecuali Gatotkaca yang di suruh oleh Cepot jelemaan untuk membawa Cepot asli dari Tumaritis.

Setelah Gatotkaca, dan rombongan Cepot dan dawala akan pergi menemui Cepot jelemaan mereka bertemu dengan para Buta atau Denawa yang bermaksud ingin menculik si Cepot. Sementara Gatotkaca, Cepot asli dan Dawala berusaha melindungi dan terjadi perkelahian. Namun Gatotkaca kalah dan disaat itu pula datanglah Cepot jelemaan dan akhirnya pertikaiaan dapat diselesaikan dan ternyata raksasa itu adalah jelmaan dari Prabu Yudistira Raja Amarta. Sedangkan si Cepot jelemaan dari Sanghiyang Tunggal ayahanda Semar Badranaya.

\section{b. Struktur wacana wayang Golek Cepot Kembar}

Struktur wacana wayang golek mengacu kepada teori Soepardi (1984) yaitu Murwa, Kakawen, Nyandra, dan Antawacana.

Murwa dalam cerita wayang Cepot kembar hanya ada satu yaitu berada di awal.yang isinya:

Nyalindung abdi ka Gusti tina pirang-pirang godaan sétan anu dilaknan. Kalayan Alloh nu kagungan sipat murah, sipat asih.maksad medar carita wayang nu jadi perlambang hirup manusa nu gelar dimarcapada. Hasil nulis para wali nu direka ku para pujangga di susun ku para empu linuhung. Hasil gawé bareng para luluhur anu parantos ngantun. Margi ieu carita wayang téh teu leupas tina simbul, silib, sindir,siloka, jeung sasmita éta anu jadi pipinding guareun urang sadaya di ieu alam marcapada.

Dalam wacana diatas jelas bahwa lakon Cepot Kembar banyak menyabit-nyabit unsur Agama, hal ini bukti bahwa wayang sudah banyak terpengaruh olah Agama Islam. Dalam murwa tersebut adalah menjelaskan bahwa wayang adalah gambaran hidup manusia, symbol untuk dipecahkan manusia yang ada di dunia.

Kakawen dalam mempunyai fungsi tertentu dalam pagelaran wayang golek. Kakawen terbagi menjadi lima bagian, yaitu kakawen sebrakan (umum), sendon, renggan, gereget saut, dan kakawen tokoh. Dari hasil analisis data kepada cerita wayang Cepot Kembar yaitu ada 11 kali kakawen, yang tergolong kepada empat bagian kakawen, yaitu (1) kakawensebrakan, (2) kakawen sendon, (3) kakawen renggan, dan (4) kakawen gereget saut.

1) Kakawen Sebrakan atau disebut kakawen kakawen umum tidak mempunyai fungsi husus seperti menggambarkan rasa marah, sedih, atau kaget. Kakawen sebrakan dalam cerita cepot kembar hanya ada satu kali yaitu kakawen "Gedon Duwur" yang isinya menceritakan Gatotkaca melayang diudara untuk mencari ayahandanya Bima.

Gedong duwur kali sambung pagulingan rana ya sepi tingtrim

Pepetétan samia murat balimbing lan jeruk manis

2)Kakawen Sendon atau disebut juga sesenden adalah lirik kakawen yang biasanya menggambarkan kesedihan yang mendalam dan rasa bingung . Dalam lakon ini ada dua sendon yaitu:

Denira ya lomundo

Uga nira ya lomundur mimiti nira yang rana

Uga nira ya lomundur mimiti nira yang rana 
Mandeg satengahing marga Wiskinastikin pinasti kersa hiyang widi

Menggambarkan rasa bingun Arjuna ketika menemui Abiasa untuk meminta gambaran siapa yang sebenarnya yang membawa layang jamus kalimusada. Sampai melamun di perjalanan.

widi

Wis ken tikin pinasti kersa hiyang

Ya kersa hiyang widi

Mapag bayah kenalara

Ya kena lara

Dalam kakawen tersebut menggambarkan keadaan rasa hati yang pasrah dengan hal yang akan datang. Kakawen ini dipakeoleh si Cepot ketika melamun karena sudah di tuduh mencuri layang jamus kalimusada.

3) Kakawen renggan asal kata dari rengga-an, yang artinya memberi manis pada pagelaran wayang dalam bentuk kakawen. Renggan dipakeuntuk mengiringi geraknya wayng dalam salah satu adegan. Dalam lakon Cepot kembar ini ada 6 kali renggan yaitu (K5Ré), (K12Ré), (K24Ré), (K31Ré), (K37Ré), dan (K54Ré).

4) Kakawen gereget saut adalah lirik dan melodi yang memberi gambaran salah satu tokoh wayng yang sedang marah. Dalam cerita ini gereget saut digambarkan ketika arjuna merasa marah kepada si Cepot.

Lan pigang prang wijenna

Arjuna Nyayat gondéwa

Napsu kang kagila-gila

Nyandra adalah pembukaan dalang yang tujuannya adalah untuk menggambarkan keadaan adegan yang akan diceritakan. Tujuannya agar para penonton tau akan cerita atau adegan yang akan dipintonkan. Nyandra dalam lakon Cepot Kembar ada 19kali. Nyandra yang paling awal dalam lkon ini yaitu menggambarkan keadaan di pertapaan parewaran atau pertapaannya Abiasa yang sangat indah. Hal ini bisa terlihat seperti di bawah ini.

"Kacarios di hiji tempat nya éta hiji tempat anu kalingkung ku gununggunung héjo lembok tutuwuhan pajegna héjo lembok dangdaunan pajegna tutuwuhan curcor cai nu haérang.marga satwa disarada manuk gedé manuk leutik pasuliwer kembang-kembang warna-warni di papaés malar pantes. Teu aya sanés ieu patempatan téh nya éta pertapan Paréwarna di alas saptarengga. Eyangna pandawa-kurawa anu kakasih Abiasa anu parantos purna bakti tilas raja Nagara Astina. Anu dina waktos ieu kasumpingan putuna $k u$ anjeun panengah pandawa Arjuna kalih buyutna kakasih Raden Gatotkaca. Sami tungkul hamarikelut dat nyembah narimangsabda ajrih ningali pamor sang begawan. Watek wantos begawan Abiasa tutuwong samanéa. Manusa terusing madu, terahing kusumah, titising andanawiri, terahing Dewa kamanusaan. Tutas tina didikan rohani kalayan jasmani. Saciduh metu sakecap nyata. Weruh sadurung winarah. Weruh sadurung winarah."

Antawacana dina carita wayang Cepot Kembar ieu aya 29 kali Antawacana. Paguneman antara tokoh wayang dengan tokoh wayang deui, tokoh wayng dengan juru alok, dan tokoh wayang dengan penonton. Contoh antawacana dalam cerita Cepot Kembar seperti ini dibawah.

Abiasa : "Kumaha bejana di puseur dayeuh? Ceunah loba nu demo"

Arjuna : "Harénghéng ku dédéngéan dina waktos ayeuna di puseur dayeuh téh"

Abiasa $\quad$ :"Moal henteu, sabab ieu mamala tina urang poho, bodo, balangah, malah beh dituna pisan mah urang dina ngajalankeun pola pamaréntahan téh jigana loba 
keur kapentingan pribadina. Numatak dimana rupa-rupa ajab nu tumiba ka ieu Nagara bongan saha?"

Arjuna : "Bongan saha éyang?"

Abiasa : "Katerangan geus méré béja yén ieu ruksakna dunya téh ku polah-polah manusa. Da ieu mah sabénérna bongan bangkong. Bongan bangkong kacai teu dimandikeun. Bongan hirup loba ngabohong pasini teu dijadikeun."

Arjuna : "Leres"

Abiasa

:"Bangkong dikongkorong kujang, kacai ngajingjing cameti. Bongan hirup loba ngabohong ditukang kana jangji teu bisa nepati. Tah éta koncinamah. Nya?"

Arjuna : :Leres kaulanun"

Abiasa : : "Kajadian naon di puseur dayeuh?"

Arjuna : :Kajadianana téh pusaka Nagara lambang kaagungan Nagara Amarta aya nu ngiwat éyang"

Gatotkaca : "Layang jamus kalimusada aya nu ngiwat"

Abiasa : :Tuh geuning, boa-boa. Tong waka nyalahkeun bangsat. Pangna meureun aya nu mawa téh boa-boa éta eusina layang jamus kalimusada téh dijieun isim hungkul. Di plangplangkeun hungkul meureun. Sok geura udag ku kanyataan. Naon ari eusi layang jamus kalimusada. Lambang téh taon?"

Arjuna

: "Aya lima perkawis, nya éta Panca Darma

\section{c. Struktur carita wayang Golek Cepot Kembar}

Struktur Cerita dalam penelitian ini yaitu berfokus kepada Fakta Cerita yang ada dalam cerita wayang Cepot Kembar dari Giriharja 3. Fakta cerita yang dimaksud yaitu Alur, Karakter, dan Latar.

Alur yang ada dalam cerita menggunakan alur maju dan dibagi menjadi 5 episode. Yaitu: (1) episode pertama menceritakan Arjuna yang menemui Abiasa, (2) episode kedua menceritakan Bima dan Gatotkaca mencari si Cepot di hutan Tibrasara, (3) episode ketiga menceritakan Arjuna dan Prabu Batara Kresna yang menemui Si Cepot, (4) episode ke empat yaitu menceritakan bertemunya Cepot Asli dan Cepot jelemaan, dan (5) episode kelima menceritakan Si Cepot dan rombongan di kepung oleh Para Denawa.

Karakter yang ada dalam cerita ini ada dalam sipat tokoh wayang itu sendiri seperti Arjuna yang mempunyai sifat pemarah dan Yudistira yang Adil dan bijaksana. Kegagahan dari jiwa satria juga digambarkan dalam karakter tokoh Gatotkaca dan Bima yang berani mati demi menemukan lambang keagungan Negaranya.

Latar yang dipakai dalam cerita ini hanya tergambar latar tempatnya saja yaitu di pertapan parewaran dan hitan tibrasara

\section{d. Nilai-nilai Etnopedagogik dalam cerita Wayang Lakon Cepot Kembar}

Wayang merupakan kesenian yang komplit. Maksud komplit yaitu kesenian yang mengabungkan unsur seni, unsur gerak, unsur sastra, unsur music. Selain dari beberapa unsur tersebut kesenian wayang golek juga mengandung nilai-nilai pendidikan. Nilai pendidikan yang dimaksud yaitu nilai etnopedagogik atau kearipan local. Nilai etnopedagogik yang dimaksud adalah nilai moral.

Nilai moraldigolongkeun jadi enam golongan yaitu (1) moral manusa kepada sang pencipta, (2) moral manusa kepada dirinya sendiri, (3) moral manusa kepada manusa lainnya, (4) moral manusa kepada alam, (5) moral manusa kepada waktu, dan (6) moral manusia kepada kebahagiaan lahir dan batinnya.

Dalam cerita wayang Cepot Kembar didapat nilai-nilai moral kemanusiaan, yaitu 
(1) moral manusa kepada penciptanya, (2) moral manusia kepada dirinya, (3) moral manusa kepada manusia lainnya, (4) moral manusia kepada alam, (5) moral manusia terhadap kebahagiaan lahir dan batin. Nilainilai moral dalam cerita wayang itu ditemui dari percakapan antar tokohnya.

Nilai moral manusa kepada penciptanya ditemukan ada tujuh kali percakapan yang menggambarkan moral manusia kepada penciptanya, yaitu (1) percakapan Abiasa dengan Arjuna tentang isi dari layang jamus kalimusada, (2) percakapan Abiasa dengan Nayaga, (3) percakapan cepot dan Nayaga, (4) percakapan Bima kalah bertarung dengan si Cepot, (5) percakapan Cepot dengan Gatotkaca, (6) percakapan Cepot memberi wejangan kepada Gatotkaca, dan (7) percakapan Cepot dan Nayaga.

Nilai moral manusia kepada dirinya sendiri ditemuka tiga kali percakapan yaitu (1) percakapan antara Bima dan si Cepot, (2) percakapan si Dawala dan si Cepot, dan (3) percakapan Cepot dan Prabu Batara Kresna mengenai bab kemanusiaan.

Nilai moral manusia kepada manusia lainnnya ditemukan dalam percakapan (1) Percakapan Abiasa pertama bertemu Arjuna, (2) percakapan Cepot dan Nayaga, (3) percakapan Cepot dan Nayaga, (4) percakapan Bima dan Cepot, (5) percakapan Gatotkaca dan Cepot, (6) percakapan Cepot dan Prabu Batara Kresna, (7) percakapan Cepot asli dan Cepot jelemaan, dan (8) Cepot, Gatotkaca, Dawala, Raja Denawa berkumpul.

Nilai moral manusia dalam mendapatkan kebahagiaan lahir dan batinnya ditemukan dalam dua percakapan yaitu (1) percakapan Cepot dan Nayaga, dan (2) percakapan Cepot dan Dawala.

Setelah menonton dan menelaah kepada cerita wayang golek Cepot Kembar terasa sekali banyak manfaatnya yang tergambar dari nilai-nilai moral yang ada dalam cerita wayang golek Cepot Kembar. Sejatinya moral-moral tersebut harus jadi penuntun hidup ketika ada di masyarakat.

\section{SIMPULAN}

Sebagai sebuah cerita, wayang golek Cepot Kembar merupakan wacana yang mempunyai struktur yang khusus yang menitik beratkan kemapada empat bagian, yaitu Murwa, Kakawen, Nyandra, Murwa, dan Antawacana. Dalam cerita wayang golek Cepot kembar ini ditemukan ada satu kali murwa, 11 kali Kakawen, 19 kali nyandra, dan 26 kali Antawacana.

Struktur cerita yang ada dalam cerita wayang golek Cepot Kembar ini digolongkan kepada tiga unsur, yaitu Alur, Karakter, danLatar. Alur yang ada dalam Cerita ini dibagi menjadi lima episode, karakter yang tergambar ada pada percakapan antar tokohnya. Dari situlah bisa dianalisis bagaimana sipat aslinya mereka, dan latar dari cerita ini hanya menggunakan latar tempat yaitu di pertapan parewaran dan hutan Tibrasara.

Nilai-nilai etnopedagogik yang tergambar dalam cerita ini digolonkan kepada 3 kategori moral yaitu (1) moral manus akepada penciptanya ada 7 kali percakapan, (2) moral manusa kepada dirinya ada 3 kali percakapan, (3) moral manusa kepada manusia lainnya ditemukan ada 8 kali percakapan dan (4) moral manusa dalam menentukan kebahagiaan lahir dan abating ada 2 kali percakapan.

\section{PUSTAKA RUJUKAN}

Mulyono, Sri. (1982) Wayang. Jakarta: PT. Inti Indayu Press.

Pasha, Lukman. (2011) Buku Pintar Wayang. Yogyakarta: In Azna Book.

Soepardi, Atik. (1984) Pagelaran Wayang Golek Purwa Gaya Priangan. Bandung: Pustaka Buana.

\section{UCAPAN TERIMA KASIH}

Ucapan terima kasih saya sampaikan kepada pembimbing tesis yang telah memberikan pengarahannya. Selain itu, terima kasih pula diucapkan kepada penyunting Jurnal Lokabasa yang berkenan memuat tulisan ini. 